leaves an impression of the early years of molecular biology which is probably truthful for Europe, at least. Molecular biology still had to claim the right of independence from biochemistry and genetics. Although major biochemical journals were published in the United States, $J M B$ was a European adventure. As molecular biology became an established field, its scope grew to absorb cell biology and development. New journals were created and $J M B$ had to face strong competition after a long period of near-monopoly. Nowadays, authors are still attracted by its reputation, by the high technical quality of

\section{Ancient bees and bronzes}

\section{Clive Gamble}

Economic Prehistory. By Grahame Clark. Cambridge University Press: 1989. Pp. 638. $£ 50, \$ 90$.

Economic Anthropology. Edited by Stuart Plattner. Stanford University Press: 1989. Pp. 487. Hok \$49.50, £29.36; pbk $\$ 16.95, £ 10.05$.

NO-ONE would contest Grahame Clark's pre-eminence as the founder of economic and social approaches to the study of our prehistoric past. But neither would anyone be surprised that his influence has not spilled over into even the disciplines most close to archaeology, as shown by the absence of citation to his works in Stuart Plattner's edited volume on Economic Anthropology.

For the archaeologist, the 32 papers in Economic Prehistory - spanning more than 40 years - will affirm again that Clark single-handedly redirected the subject away from sterile museology, where the past was treated like stamp collecting, and towards the study of what people did. Clark put people back into the past by concentrating on hitherto neglected topics in the prehistory of northwest Europe, such as fishing, fowling and whale hunting, as well as using the pollen evidence for forest clearance and linking this to farming settlement. In the earliest paper reprinted here, "Bees in Antiquity" (1942), Clark summed up his view in a lapidary phrase "which tell us more, the bees or the bronzes?", one he returned to in his retrospective (1974). This 'question-begging question' encapsulates Clark's ecological approach, with its emphasis on the inter-relation between environment and society that links honey with land use and beeswax with bronzecasting. Such a holistic approach was summarized in diagrams that long predated the systems analysis of prehistoric societies. Clark's ability to connect evidence from different spheres of activity the typography and by the convenience of having almost no limitation in length. Yet high subscription costs and slow publication are serious drawbacks. $J M B$ has lost some of its audience even as its scientific excellence is maintained. Is that a sign that old age starts at thirty for a scientific journal, or shall we trust Balzac's word that "a lady of thirty has irresistible appeal on a young man", and count on the new generation of molecular biologists to match the one that created $J M B$ ?

Joel Janin is Professor of Biophysics at the Université Paris-Sud, 91405 Orsay, France.

and present them through his classic case studies of hunting camps, such as his own excavations at Star Carr, or sealing villages around the Baltic, established the alternative to museology as well as the sterility of typological analysis for its own sake.

These studies mark Clark out as an optimist in terms of what can be done with prehistoric data. Significantly, his book World Prehistory (1961) was dedicated to two other archaeological optimists, Childe and Crawford, who with Clark lay claim to being by far the most important British prehistorians of the century because of their visions of what the subject could contribute to understanding human history. Clark built his on economic foundations which, he tells us, were never the key but merely a useful approach in attaining a wider goal. What this goal might be emerges in the 13 papers grouped here under the headings of "World Prehistory" and "Archaeology and Society", mostly written between 1960 and 1980.

Clark claims that "the substance of prehistory is no less than the emergence and self-realisation of humanity itself" (1968) and recognized archaeology's appeal in telling us about our identity (1980). Such statements do not fit easily with archaeology's present mood of introspection and particularism. But as Robin Dennell has pointed out, Clark is one of the few prehistorians who have tried to tackle the question of archaeology's relevance. Although we may not accept his championing of cultural diversity and the retention of separate cultures as a bulwark against what he sees as dangerous contemporary currents of a homogenizing culture, or the value of social élites as patrons of great art, his willingness to tackle contentious issues has to be acknowledged. At the same time, in his penetrating essay on human diversity (1979), Clark shows he is well aware that the esteem for archaeology flows from "its ability to dignify and validate the status quo by investing it with the sanction of antiquity" and that as a result archaeologists, unlike anthropologists, conform rather than protest. Although accurately describing the social role of most archaeologists, Clark's work has not provided the springboard for any radical critique although protest, as shown by recent battles over reburial issues, the Rose theatre in London, and the corruption of heritage, academic freedom and apartheid, is now increasingly part of the archaeological agenda.

Clark's papers reveal two main events which shaped his thinking: the wartime mechanization of the countryside and the loss of folk traditions (1951); and the loss of the British Empire, indicated by his papers on Australia (1968) and world prehistory. The first was a legacy from O.G.S. Crawford: knowledge of how traditional agriculture worked now had to be learnt from books and passed on to students. What was once common knowledge now became articulate explanation, so elegantly contained in Prehistoric Europe: the Economic Basis (1952). The second resulted in Clark's global empire of Cambridge graduates equipped with his vision and techniques which were enhanced wherever they also discovered that, outside the joint Cambridge faculty, archaeology could be combined with anthropology in more than just name.

What many of these students know, but what is missing in this remarkable set of papers, and even in Clark's invited lectures to learned US societies, is that the intellectual base of the discipline has shifted across the Atlantic. The present and indeed postwar dominance of anthropology by researchers in the United States is revealed in the excellent collection of thematic essays in Stuart Plattner's volume. Substantivist and formalist, marxist and development economics are thoroughly described and discussed in what will become a standard and muchneeded undergraduate text. Wider issues of trade, markets, the role of women, the informal economy and common property, as well as chapters on hunters and gatherers and horticulturalists, are covered in 15 commissioned papers. The often seamless transition from economic anthropology to development economics underlies the embededness of the discipline in the present, retaining its identity only through its insistence on analytical scale within an otherwise all-comers paradigm.

The aim of the authors of these papers is to set out what economic anthropology knows about the world, and this is achieved with great success and various perspectives. As a result it is not difficult to see why Clark's present economic values and social positions, justified by his reading of the past, are ignored in these essays. For, as Frank Cancian concludes in his contribution on peasant communities, "there are many reasons to think that active peasants and their descendants will put their own stamp on the future"

Clive Gamble is in the Department of Archaeology, University of Southampton, Southampton SOg $5 \mathrm{NH}$, UK. 